УДК 551.582:551.584:550.42:502.175

\title{
МЕТЕОРОЛОГИЧЕСКИЕ УСЛОВИЯ ФОРМИРОВАНИЯ ПОВЕРХНОСТНОГО СТОКА НАНОСОВ В ПЕРИОД ВЕСЕННЕГО СНЕГОТАЯНИЯ В ГОРОДСКОЙ СРЕДЕ
}

\author{
Селезнев Андриан Анатольевич1,2, \\ sandrian@rambler.ru
}

Тетерин Александр Федорович ${ }^{1}$, taf@ecko.uran.ru

Ярмошенко Илья Владимирович1, ivy@ecko.uran.ru

1 Институт промышленной экологии Уральского отделения РАН, Россия, 620219, г. Екатеринбург, ул. Софььи Ковалевской, 20.

2 Уральский Федеральный Университет имени первого Президента России Б.Н. Ельцина, Россия, 620002, г. Екатеринбург, ул. Мира, 19.

\begin{abstract}
Актуальность исследования обусловлена необходимостью изучения процессов осадкообразования на урбанизированной территории, которые снижают качество городской среды и оказывают негативное влияние на экологическую ситуацию. Цель: проанализировать метеорологические условия формирования поверхностного стока наносов в крупном городе в период интенсивного весеннего снеготаяния.

Объект: урбанизированная территория города Екатеринбурга.

Методы: изучение метеорологических условий за холодные периоды 2015-2016 и 2016-2017 г2., а также в весенние сезоны 2016 и 2017 г2.; оценка особенностей и различий метеорологических параметров и процессов, оказавших основное влияние на сток наносов весной 2016 и 2017 г2.

Результаты. Ретроспективно восстановлены метеорологические условия холодных периодов 2015-2016 и $2016-2017$ г2. и в весенние сезоны 2016 и 2017 г2. Были проанализированы метеорологические величины и процессы, оказавшие существенное влияние на поверхностный сток воды на урбанизированной территории: термический режим приземного воздуха, атмоссрерные осадки, снежный покров, снеготаяние, промерзание и оттаивание почвогрунтов. Установлено, что метеорологические условия весен 2016 и 2017 га. существенно отличались друг от друга, что отразилось на формировании более интенсивного грязевого осадка в 2016 г. Весной в городской среде следующие погодные факторы являются определяющими при формировании поверхностного стока: запас воды, накопленный в снежном покрове за холодный период года; особенности термического режима в период снеготаяния (дружность весны, возвраты холодов); атмосфрерные осадки и интенсивность оттаивания грунта в период снеготаяния. Полученные результаты могут быть использованы при планировании мероприятий для улучшения экологической ситуации на урбанизированной территории.
\end{abstract}

Ключевые слова:

Урбанизированная среда, седиментогенез, метеорологические условия, снеготаяние, поверхностный сток, наносы, грязевой осадок, Екатеринбург.

\section{Введение}

Одним из процессов, определяющих геохимическую трансформацию верхней части геологического разреза городских территорий, является образование рыхлого осадочного материала в результате действия естественных и антропогенных факторов $[1,2]$. К природным факторам седиментогенеза в городской среде относятся: выветривание и эрозия грунтов, дорожных покрытий и строительных конструкций. Антропогенные процессы включают разрушение покрытий автотранспортом, производство работ, связанных с нарушением целостности покрытий, разработкой грунта и др. За счет антропогенных факторов интенсивность современного осадкообразования в урбанизированной среде на порядки выше, чем в природных ландшафтах, и может достигать нескольких сотен тонн на квадратный километр в год $[3,4]$.

Перемещение наносов в ходе поверхностного стока и аккумуляция осадочного материала на пониженных участках микрорельефа городского ландшафта представляют собой как экологическую $[1,5,6]$, так и коммунальную проблему $[7,8]$. В урбанизированной среде поверхностные наносы образуют грязевой осадок - твердые частицы минерального и антропогенного происхождения, отложенные в локальных понижениях дорог, проездов, тротуаров, газонов и других участков. Накопление этого компонента на улицах и во дворах существенно снижает качество и ухудшает восприятие городской среды. Грязевые отложения являются неточечным источником загрязнения атмосферы твердыми взвешенными частицами и поллютантами [2]. Твердые частицы заиливают ливневую канализацию, способствуют уплотнению городских почв и как результат увеличивают поверхностный сток [7]. Негативный эффект значительно возрастает при нарушении технологий благоустройства территорий города и недостаточной уборке [8]. Поступление наносов с урбанизированных территорий в речные системы делает города источником загрязнения вод в глобальном масштабе, а также изменяет морфологию русел $[9,10]$. 
При планировании устойчивого, экологически безопасного развития городов в условиях возрастающей антропогенной, в частности автотранспортной, нагрузки необходимо учитывать происходящие на урбанизированной территории процессы осадкообразования. Актуальность изучения наносов также связана с тем, что поверхностные грязевые отложения могут использоваться в качестве геоиндикаторного объекта, позволяющего контролировать экологогеохимические процессы в городской среде $[6,11]$.

Помимо природных факторов и антропогенного воздействия на отложение наносов оказывают влияние метеорологические условия [12]. Наиболее выражено влияние метеоусловий в зимний и весенний сезоны. В контексте городского седиментогенеза образование снежного покрова может рассматриваться как затяжной процесс поверхностного стока атмосферных осадков, консервирующего поверхностный осадок на продолжительное время. Как показало исследование источников и причин загрязнения территории города, проведенное в Екатеринбурге в 2017 г., содержание твердого осадка в пробах снегогрязевой пульпы, которая образуется в результате перемешивания поверхностного осадка снега колесами автомобилей на дорогах и в проездах, а также в кучах снега, складированных вдоль дорог, в феврале 2016 г. составляло в среднем 25 г/л, что соответствует площадному накоплению 1,2 кг/м² [13]. Интенсивное весеннее снеготаяние за короткий период времени высвобождает накопленный осадочный материал и способствует образованию грязевого осадка. В городах, расположенных в климатической зоне с продолжительной снежной зимой, значительное количество грязевого осадка в период снеготаяния является актуальной, общественно значимой проблемой.

Качественные экспертные оценки стока наносов с талыми водами, проведенные в Екатеринбурге весной 2016 и 2017 гг., показали, что в период интенсивного снеготаяния 2016 г. образовалось заметно большее количество грязевого осадка, чем в 2017 г. Можно предполагать, что сравнение условий формирования поверхностного стока наносов за эти два периода позволит определить основные метеорологические факторы, оказывающие влияние на этот процесс в урбанизированной среде. Целью настоящего исследования является анализ метеорологических условий формирования поверхностного стока наносов на территории города в период снеготаяния. Исследование проведено на примере Екатеринбурга.

\section{Материалы и методы}

Екатеринбург - административный центр Уральского федерального округа и Свердловской области, крупнейший на Урале промышленный, культурный и научно-образовательный центр. Площадь городской территории составляет $468 \mathrm{kм}^{2}$. Это четвертый по численности населения город в России, по состоянию на 1 января 2018 г. в городе проживало примерно 1,5 млн человек. Город Екатеринбург расположен в глубине Евразийского материка, на стыке восточных предгорий Среднего Урала и Зауральской складчатой возвышенности, в таежной зоне, подзоне южной тайги. Характер рельефа крупнохолмистый $[14,15]$.

По генетической классификации климатов Б.П. Алисова, Екатеринбург находится в умеренном климатическом поясе континентальной лесной Западно-Сибирской области [16]. По классификации климатов А.А. Григорьева и М.И. Будыко, Екатеринбург расположен в зоне II3D влажного климата с умеренно теплым летом, умеренно суровой и снежной зимой $[17,18]$.

В районе Екатеринбурга преобладает западный перенос воздушных масс. Средний Урал является преградой на пути воздуха, поступающего с акватории Северной Атлантики. Поэтому на западных предгорьях Среднего Урала выпадет больше атмосферных осадков, чем на восточных. Следствием этого в холодный период года является формирование менее мощного снежного покрова на восточных предгорьях Среднего Урала по сравнению с западными предгорьями [19]. Многолетний средний индекс континентальности по С.П. Хромову $[18,20]$ для Екатеринбурга составляет 86,18 \%, по Ценкеру - 52 \% [14].

Многолетний средний индекс континентальности по атмосферным осадкам, предложенный в 1976 г. Ц.А. Швер [21], для Екатеринбурга равен 1,84, что соответствует континентальному типу климата. Эта величина, как и индекс континентальности по Хромову, не является постоянной.

Холодный период, когда средняя месячная температура воздуха ниже $0{ }^{\circ} \mathrm{C}$, в Екатеринбурге в среднем продолжается с ноября по март (151 день), средняя температура воздуха за данный период составляет $11,2{ }^{\circ} \mathrm{C}$. При отрицательных температурах происходит накопление атмосферных осадков в виде снежного покрова. Многолетняя средняя температура января равна $-15,3{ }^{\circ} \mathrm{C}$, а июля $-+17,4{ }^{\circ} \mathrm{C}[14]$. В силу изменений климата многолетняя средняя температура января повысилась до $-14,7^{\circ} \mathrm{C}$, а июля $-+17,8^{\circ} \mathrm{C}[30]$. В силу географического положения и континентальности климата средняя температура зимой в Екатеринбурге значительно ниже, чем в крупных городах Европы и в большинстве крупных городов России. В то же время средняя июльская температура не ниже, чем в североевропейских городах.

Городские ландшафты испытывают высокую антропогенную нагрузку, обусловленную большим числом автомобилей. Екатеринбург - четвертый город России по числу легковых автомобилей (437,3 тыс. штук [22]).

В работе проанализированы следующие метеорологические характеристики за холодные периоды 2015-2016 и 2016-2017 гг., а также в весенние сезоны 2016 и 2017 гг.: термический и влажностный режимы; атмосферные осадки; запас воды, накопленный в снежном покрове за холодный период; высота, даты появления и схода снежного покрова; промерзание и оттаивание грунтов, процесс снеготаяния. Конкретные значения метеорологических величин по метеостанции Екатеринбург (WMO_ID=28440) за исследуемый период были получены с сайта «Расписание Погоды» [23]. В качестве норм были использованы 
многолетние средние значения основных метеорологических величин из последнего официального издания по климату Уральского региона, научноприкладного справочника по климату СССР [24].

Расчет промерзания грунтов проводился согласно «СП 22.13330.2011. Основания зданий и сооружений. Актуализированная редакция СНиП 2.02.01-83*». Глубину сезонного промерзания грунта для районов, с глубиной промерзания до 2,5 м, определяют по формуле:

$$
d=d_{0}\left(M_{t}\right)^{0,5},
$$

где $M_{t}$ - безразмерный коэффициент, численно равный сумме абсолютных значений среднемесячных отрицательных температур за зиму в данном районе; $d_{0}$ - величина, принимаемая равной 0,23 м для суглинков и глин; супесей, песков мелких и пылеватых - 0,28 м; песков гравелистых, крупных и средней крупности - 0,30 м; крупнообломочных грунтов 0,34 м. Так как в районе Екатеринбурга преобладают суглинки, $\mathrm{d}_{0}$ приняли равным 0,23. Среднюю глубину промерзания грунта при наличии снежного покрова определяли в зависимости от морозопродолжительности (произведение средней температуры воздуха на продолжительность морозного периода) и толщины снежного покрова по многолетним средним данным [24], а глубину промерзания грунта за конкретный месяц и год - по фактическим данным для метеостанции Екатеринбург [23].

Средняя скорость оттаивания суглинков в Свердловской области и в Екатеринбурге по [25] составляет 4 см/сутки. Весной оттаивание грунта начинается после схода снежного покрова.

Для городской среды, исходя из уравнения водного баланса и не учитывая поверхностный и подземный приток воды извне, конденсацию водяного пара и изменение количества воды в пределах территории города [26], весной при снеготаянии суточный поверхностный сток воды ( $S R$, мм/сутки) рассчитывали по формуле:

$$
S R=S M+P r-E-I,
$$

где $S M$ - снеготаяние; $P r$ - атмосферные осадки за период снеготаяния; $E$ - испарение; $I$ - инфильтрация воды в грунт; все компоненты поверхностного стока имеют размерность мм/сутки. Затем определялся суммарный (накопленный) поверхностный сток воды как сумма суточных поверхностных стоков.

Расчет суточного снеготаяния (SM, мм/сутки) проводили согласно [27] по формуле:

$$
S M=a \cdot t_{a}
$$

где $a$ - коэффициент стаивания, мм $/\left({ }^{\circ} \mathrm{C} \cdot\right.$ сутки $) ; t_{a}-$ средняя суточная температура воздуха $\left({ }^{\circ} \mathrm{C}\right)$. Оценку снеготаяния проводили для двух участков на урбанизированной территории: для открытых газонов и площадок [максимальное снеготаяние, коэффициент стаивания $5 \mathrm{~mm} /\left({ }^{\circ} \mathrm{C} \cdot\right.$ сутки $\left.)\right]$, для лесопарков, затененных газонов и площадок [минимальное снеготаяние, коэффициент стаивания $1,4 \mathrm{~mm} /\left({ }^{\circ} \mathrm{C} \cdot\right.$ суутки $\left.)\right]$.

Суточные суммы атмосферных осадков (Pr) выбирались по метеостанции Екатеринбург [23].
При температуре воздуха выше $0{ }^{\circ} \mathrm{C}$ суточное испарение с водной поверхности $(E$, мм/сутки), согласно [28], рассчитывали по формуле:

$$
E=0,82 d^{0,8}
$$

где $d$ - средний суточный дефицит влажности воздуха, мм рт. ст.

Средние суточные относительные влажности воздуха выбирались по метеостанции Екатеринбург [23]. Равновесное давление насыщенных водяных паров определялось по психрометрическим таблицам при положительной температуре воздуха над водой, при отрицательной температуре воздуха надо льдом. Средний суточный дефицит влажности воздуха рассчитывали как разность давления насыщенного и парциального давления водяного пара.

Суточную инфильтрацию (I, мм/сутки) в расчетах принимали по [29] с учетом того, что, минимальное значение коэффициента фильтрации для суглинков составляло 5 мм/сутки. Так как степень покрытия снежным покровом территории весной изменялась от 100 через 50 до $0 \%$ [23], то в расчетах коэффициент фильтрации принимали равным 5; 2,5 и 0 мм/сутки соответственно.

Расчет испарившейся за холодный период воды $(E$, мм/месяц) проводился за каждый месяц по формуле [30]:

$$
E=0,37 n d,
$$

где $n$ - число суток в месяце; $d$ - средний месячный дефицит влажности воздуха, мм рт.ст.

\section{Результаты}

Среднемесячные значения основных метеорологических характеристик по метеостанции Екатеринбург за период с 2015 по 2017 гг. представлены в табл. 1. Средняя годовая температура воздуха в Екатеринбурге в 2015, 2016 и 2017 гг. соответственно была 3,6; 3,7 и $3,5^{\circ} \mathrm{C}$, что на 2,$4 ; 2,5$ и $2,3{ }^{\circ} \mathrm{C}$ выше нормы (средних многолетних значений). Средняя температура воздуха в холодный период 2015-2016 гг. составила $-7,6^{\circ} \mathrm{C}$, в холодный период 2016-2017 гг. - $-10,3{ }^{\circ} \mathrm{C}$, что соответственно на 3,6 и $0,9^{\circ} \mathrm{C}$ выше нормы (табл. 1).

По результатам анализа термического режима приземной атмосферы за холодные периоды 2015-2016 и 2016-2017 гг. положительные аномалии (разница фактического по [23] и среднемноголетнего значения по [24]) средних месячных температур воздуха преобладали над отрицательными, кроме того, положительные аномалии были более значительными.

Осенью 2015 г. первый переход средней суточной температуры воздуха через $0^{\circ} \mathrm{C}$ произошел 9 октября, устойчивый переход состоялся 6 ноября, что на 17 дней позже средней многолетней даты. В 2016 г. средняя суточная температура воздуха через $0{ }^{\circ} \mathrm{C}$ первый раз перешла 24 февраля. Весной 2016 г. устойчивый переход через $0{ }^{\circ} \mathrm{C}$ произошел 25 марта, на 12 дней раньше средней даты [14]. Осенью 2016 г. переход средней суточной температуры воздуха через $0{ }^{\circ} \mathrm{C}$ впервые наблюдался 15 октября, а устойчивый переход- 26 октября, что на 6 дней позже средней 
даты. В 2017 г. средняя суточная температура воздуха первый раз перешла через $0{ }^{\circ} \mathrm{C} 21$ февраля при трехдневной оттепели. Весной 2017 г. устойчивый переход средней суточной температуры воздуха через $0{ }^{\circ} \mathrm{C}$ произошел 6 апреля, что соответствует многолетним наблюдениям [14]. Таким образом, в рассматриваемые холодные периоды наблюдалось позднее установление отрицательных температур осенью и раннее положи- тельных температур весной по сравнению с многолетними нормами, что косвенно указывает на потепление. Следует отметить, что ранее для Екатеринбурга были выявлены положительные линейные тренды в многолетнем ходе температуры воздуха с максимумом в марте [30]. Преобладание положительных аномалий температуры воздуха в холодный период года свидетельствует о потеплении климата в городе.

Таблица 1. Метеорологические условия в Екатеринбурге в 2015-2017 г2.

Table 1. Meteorological conditions in Yekaterinburg in 2015-2017

\begin{tabular}{|c|c|c|c|c|c|c|c|c|c|c|c|c|c|c|}
\hline \begin{tabular}{|l|} 
Годы \\
Years \\
\end{tabular} & $\begin{array}{l}\text { Параметр } \\
\text { Parameter }\end{array}$ & I & II & III & IV & V & VI & VII & VIII & IX & $\mathrm{X}$ & XI & XII & $\begin{array}{l}\text { Год } \\
\text { Year }\end{array}$ \\
\hline & $\begin{array}{l}\text { Hopмa ta } \\
\text { Norm ta, }{ }^{\circ} \mathrm{C}\end{array}$ & $-15,5$ & $-13,6$ & $-6,9$ & 2,7 & 10,0 & 15,1 & 17,2 & 14,9 & 9,2 & 1,2 & $-6,8$ & $-13,1$ & 1,2 \\
\hline 2015 & \multirow{3}{*}{$\mathrm{t}_{\mathrm{a}},{ }^{\circ} \mathrm{C}$} & $-11,7$ & $-6,0$ & $-1,9$ & 4,9 & 13,3 & 19,5 & 15,4 & 13,2 & 11,4 & 0,0 & $-7,4$ & $-7,4$ & 3,6 \\
\hline 2016 & & $-15,8$ & $-4,1$ & $-3,5$ & 7,5 & 13,4 & 17,6 & 20,1 & 23,0 & 11,1 & 0,7 & $-10,5$ & $-15,3$ & 3,7 \\
\hline 2017 & & $-13,2$ & $-11,1$ & $\begin{array}{l}-1,6 \\
\end{array}$ & 5,0 & 10,3 & 15,5 & 18,0 & 17,6 & 9,5 & 2,1 & $-2,5$ & $-7,8$ & 3,5 \\
\hline & $\begin{array}{l}\text { Норма } V, \mathrm{~m} / \mathrm{c} \\
\text { Norm } V, \mathrm{~m} / \mathrm{s}\end{array}$ & 3,5 & 3,6 & 3,8 & 3,7 & 3,7 & 3,4 & 3,0 & 2,9 & 3,4 & 4,0 & 4,1 & 3,6 & 3,6 \\
\hline 2015 & \multirow{3}{*}{$\mathrm{V}, \mathrm{M} / \mathrm{c}(\mathrm{m} / \mathrm{s})$} & 3,1 & 3,3 & 3,2 & 3,1 & 1,9 & 2,4 & 2,9 & 2,7 & 2,2 & 3,0 & 2,8 & 2,7 & 2,8 \\
\hline 2016 & & 2,6 & 2,7 & 2,5 & 2,4 & 2,3 & 2,4 & 2,2 & 2,0 & 2,3 & 2,0 & 2,6 & 2,8 & 2,4 \\
\hline 2017 & & 2,6 & 2,8 & 3,1 & 3,8 & 3,0 & 2,7 & 2,0 & 2,1 & 2,1 & 2,4 & 2,7 & 2,2 & 2,6 \\
\hline & $\begin{array}{l}\text { Норма Max V, } \mathrm{m} / \mathrm{c} \\
\text { Norm Max V, } \mathrm{s} / \mathrm{s}\end{array}$ & 23 & 25 & 24 & 24 & 22 & 30 & 24 & 30 & 20 & 29 & 22 & 23 & 30 \\
\hline 2015 & \multirow{3}{*}{ Max V, $\mathrm{N}$} & 18 & 17 & 16 & 18 & 15 & 18 & 20 & 15 & 17 & 19 & 15 & 15 & 20 \\
\hline 2016 & & 16 & 16 & 22 & 18 & 21 & 18 & 15 & 17 & 19 & 13 & 16 & 15 & 22 \\
\hline 2017 & & 15 & 17 & 15 & 19 & 21 & 20 & 16 & 12 & 17 & 17 & 14 & 13 & 21 \\
\hline & $\begin{array}{l}\text { Норма Pr, мм } \\
\text { Norm } \operatorname{Pr}, \mathrm{mm}\end{array}$ & 20 & 17 & 20 & 26 & 49 & 69 & 84 & 74 & 45 & 36 & 30 & 27 & 497 \\
\hline 2015 & \multirow{3}{*}{$\operatorname{Pr}, \mathrm{MI}$} & 19,0 & 5,1 & 6,8 & 40,0 & 91,0 & 61,0 & 120,0 & 117,0 & 29,0 & 72,0 & 30,0 & 40,0 & 630,9 \\
\hline 2016 & & 35,0 & 6,2 & 21,0 & 61,0 & 6,6 & 45,0 & 31,0 & 24,0 & 57,0 & 35,0 & 55,0 & 26,0 & 402,8 \\
\hline 2017 & & 30,0 & 14,0 & 13,0 & 26,0 & 36,0 & 106 & 107 & 47 & 33 & 32 & 19 & 23 & 486,0 \\
\hline & $\begin{array}{l}\text { Hорма Н сн.п., см } \\
\text { Norm H s.c., cm }\end{array}$ & 29,3 & 36,3 & 33,3 & 7 & - & - & - & - & - & 3 & 9,7 & 21 & 19,9 \\
\hline 2015 & \multirow{3}{*}{$\mathrm{H} \mathrm{cH}$} & 30,4 & 29,7 & 16,3 & 0,4 & - & - & - & - & - & 1,9 & 8,8 & 19,6 & 15,3 \\
\hline 2016 & & 40,7 & 52,3 & 45,5 & 10,8 & $\begin{array}{lll}- & \\
\end{array}$ & - & $\begin{array}{llll}- & & & \end{array}$ & $\begin{array}{lll}- & \\
-\end{array}$ & $\begin{array}{llll}- & & & \end{array}$ & 2,5 & 19,4 & 35,2 & 29,5 \\
\hline 2017 & & 46,4 & 47,9 & 35,1 & 12,3 & - & - & - & - & - & 2,1 & 3,2 & 12,9 & 22,8 \\
\hline & $\begin{array}{l}\text { Норма Max H сн.п., см } \\
\text { Norm Max H s.c., cm }\end{array}$ & 72 & 77 & 77 & 65 & - & - & - & - & - & 32 & 38 & 77 & 77 \\
\hline 2015 & \multirow{3}{*}{$\begin{array}{l}\text { Max H сн.п., см } \\
\text { Max H s.c., cm }\end{array}$} & 37 & 34 & 26 & 1 & - & - & - & - & - & 7 & 12 & 33 & 37 \\
\hline 2016 & & 58 & 58 & 51 & 26 & - & - & - & - & - & 6 & 30 & 39 & 58 \\
\hline 2017 & & 53 & 49 & 49 & 22 & - & - & - & - & - & 6 & 10 & 19 & 53 \\
\hline & $\begin{array}{l}\text { Норма D промерз. гр., м } \\
\text { Norm D s.f., m } \\
\end{array}$ & 1,37 & 1,61 & 1,72 & - & - & - & - & - & - & - & 0,60 & 1,03 & 1,72 \\
\hline 2015 & \multirow{3}{*}{$\begin{array}{l}\text { D промерз. гр., } \mathrm{M} \\
\text { D s.f., m }\end{array}$} & 1,20 & 1,33 & $\begin{array}{l}1,37 \\
\end{array}$ & - & - & - & - & - & - & - & 0,63 & 0,88 & 1,37 \\
\hline 2016 & & 1,27 & 1,35 & 1,42 & - & - & - & - & - & - & - & 0,75 & 1,17 & 1,42 \\
\hline 2017 & & 1,44 & 1,63 & 1,65 & - & - & - & - & - & - & - & 0,36 & 0,74 & 1,65 \\
\hline
\end{tabular}

Примечание: $t_{a}$ - средняя месячная или годовая температура воздуха, $V$ - средняя месячная или годовая скорость ветра, Мах V-максимальный порыв ветра, Нормы метеовеличин - многолетние средние значения по [24] или по [14], Pr-месячные или годовые суммы осадков по осадкомеру с поправками на смачивание, Н сн.п. - средняя высота снежного покрова, Мах Н сн.п. - максимальная высота снежного покрова, D промерз. гр. - глубина промерзания грунта на конеи месяиа без снежного покрова.

Note: $t_{a}$ - the average monthly or annual air temperature, $V$ - the average monthly or annual wind velocity, Max $V-$ the maximum gust of wind, the Norms of meteorological elements - long-term average values from [24] or [14], Pr - the monthly or annual amount of precipitation in the precipitation gauge with corrections for wetting, $H$ s.c. - the average depth of snow cover, Max H s.c. - the maximum depth of the snow cover, D s.f. - depth of soil freezing at the end of the month without snow cover.

Годовые суммы осадков в Екатеринбурге в 2016 и 2017 гг. составили соответственно 402,8 и 486 мм [23], что на 94,2 и 11 мм ниже нормы [24]. За период 2015-2017 гг. аномалии месячных сумм осадков были заключены в диапазоне от +43 мм в августе 2015 г. до 53 мм в июле 2016 г. (табл. 1). Ранее в публикации [31] уже был сделан вывод, что незначительные величины линейных трендов, их разнонаправленность и малые значения коэффициентов детерминации в многолетнем ходе месячных сумм атмосферных осадков на метеостанции Екатеринбург свидетельствуют, скорее всего, о наличии сложных колебаний в многолетнем ходе, чем об однонаправленных изменениях в их режиме.

Осенью 2015 г. первый снежный покров появился 8 октября (на 5 дней раньше средней даты). Временный снежный покров устанавливался 12-15 и 20-27 октября. 
Устойчивый снежный покров образовался 30 октября (на 7 дней раньше средней даты). Зимой 2015-2016 гг. наибольшая высота снежного покрова зафиксирована в феврале 2016 г. и составляла 52,3 см, что на 16 см больше нормы. Наибольшие из максимальных высот снежного покрова 58 см были отмечены в конце января - начале февраля 2016 г. В марте 2016 г., к окончанию зимы, средняя высота снежного покрова составляла 45,5 см, что на 12,2 см выше нормы (табл. 1, рисунок). С 7 по 10 марта 2016 г. была отмечена максимальная мартовская высота снежного покрова, которая равнялась 51 см. К 31 марта 2016 г. высота снежного покрова уменьшилась до 33 см, к 1 апреля она ещё уменьшилась до $26 \mathrm{~cm}$.

Осенью 2016 г. первый снежный покров был зафиксирован 13 октября (на 5 дней позже, чем осенью
2015 г.). Временный снежный покров устанавливался $14,16,18-29$ октября (степень покрытия достигала $50 \%$ территории города). Устойчивый снежный покров образовался 30 октября (на 7 дней раньше средней даты и в тот же день, что и осенью 2015 г.). Зимой 2016-2017 гг. наибольшая средняя высота снежного покрова была отмечена в феврале 2017 г. и равнялась 47,9 см, что на 11,6 см выше нормы. А наибольшая из максимальных высот снежного покрова наблюдалась 9 января 2017 г. и составила 53 см. В марте 2017 г., к окончанию зимы 2016-2017 гг., средняя высота снежного покрова составляла $35,1 \mathrm{~cm}$, что на 1,8 см выше нормы и на 10,4 см меньше, чем в конце зимы 2015-2016 гг. (табл. 1, рисунок). 31 марта 2017 г. высота снежного покрова была 22 см.

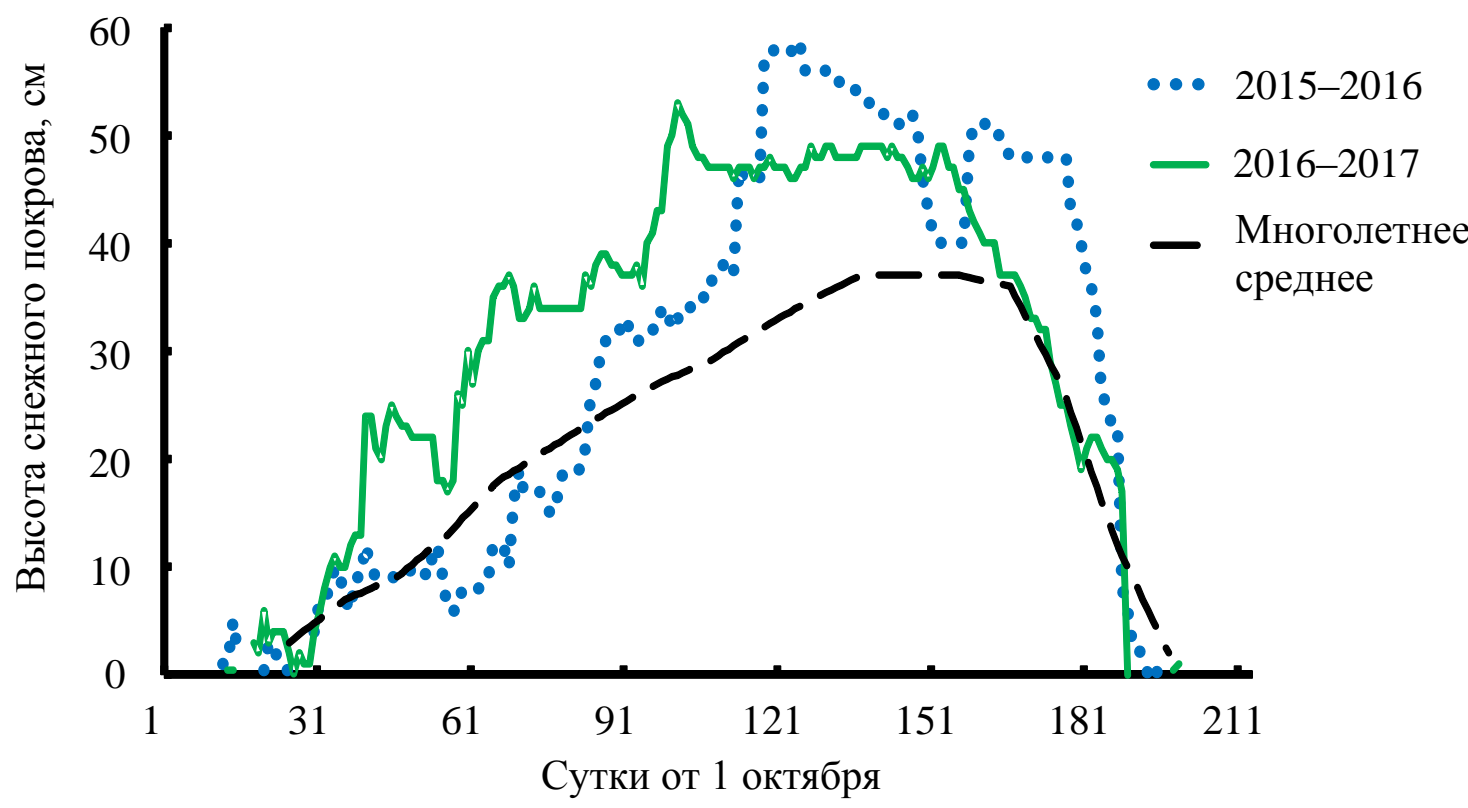

Рисунок. Динамика высоты снежного покрова в холодный период 2015-2016 г2., 2016-2017 г2. и многолетних средних высот снежного покрова за холодный период [24]

Figure. Dynamics of snow depth in cold period of 2015-2016, in cold period of 2016-2017 and perennial average snow depth for cold period [24]

За холодный период 2015-2016 гг. накоплено 132,2 мм осадков, а за холодный период 2016-2017 годов - 138 мм, что соответственно на 18,2 и 24 мм выше нормы. В холодный период 2015-2016 гг. с поверхности снега испарилось 31 мм выпавших осадков, а за холодный период 2016-2017 гг. - 34,2 мм. Таким образом, за холодный период 2015-2016 гг. в снежном покрове накоплен запас воды 101,2 мм, а за холодный период 2015-2016 гг. - на 2,6 мм больше, т. е. 103,8 мм.

Весной 2016 г. устойчивый снежный покров разрушился 5 апреля (на 3 дня раньше средней даты), а последний снежный покров был отмечен 11 апреля (на 15 дней раньше средней даты). За холодный период 2015-2016 гг. было отмечено 158 дней с устойчивым снежным покровом, что на 5 дней больше климатической нормы. Весной 2016 г. интенсивное круглосуточное снеготаяние при средних суточных температурах воздуха выше $0{ }^{\circ} \mathrm{C}$ продолжалось 18 суток - с 25 марта по 11 апреля. Сумма средних суточных тем- ператур воздуха за период интенсивного снеготаяния составила $+55,9^{\circ} \mathrm{C}$. Днем снеготаяние было менее интенсивным, оно наблюдалось при максимальных температурах воздуха выше $0{ }^{\circ} \mathrm{C}$ и продолжалось 6 дней: с 9 по 12 марта, 19 марта и 24 марта. Сумма максимальных температур воздуха за период дневного снеготаяния была равна $+23,0{ }^{\circ} \mathrm{C}$. Весной 2016 г. в период активного снеготаяния с 1 по 11 апреля за 5 дней в виде мокрого снега, дождя и ливневого дождя выпало 25 мм осадков.

Весной 2017 г. устойчивый снежный покров разрушился 7 апреля (на 1 день раньше средней даты и на 2 дня позже весны 2016 г.). За холодный период 2016-2017 гг. было 163 дня с устойчивым снежным покровом, что на 10 дней больше многолетнего среднего значения. Временный снежный покров наблюдался 9, 11, 16-17 апреля. Последний снежный покров был отмечен 17 апреля (на 9 дней раньше средней даты и на 6 дней позже весны 2016 г.). Весной 2017 г. интен- 
сивное круглосуточное снеготаяние продолжалось 9 суток: с 4 по 7, с 25 по 27 и 29 марта, 6 апреля. Сумма средних суточных температур воздуха за период интенсивного снеготаяния была $+9,5{ }^{\circ} \mathrm{C}$, что на $46,4{ }^{\circ} \mathrm{C}$ меньше, чем весной 2016 г. Дневное снеготаяние продолжалось 32 дня: с 2 по 30 марта, с 3 по 5 апреля. Сумма максимальных температур воздуха за период дневного снеготаяния составила $+104,0{ }^{\circ} \mathrm{C}$, что на $81{ }^{\circ} \mathrm{C}$ больше, чем весной 2016 г. В период с 1 по 11 апреля был отмечен 1 день с незначительным количеством осадков - 1,2 мм в виде снега, что гораздо меньше (на 23,8 мм), чем в 2016 г.

Весна 2016 г. была дружной, (стремительной, бурной), интенсивное круглосуточное снеготаяние продолжалось 18 суток - с 25 марта по 11 апреля. Средние суточные температуры воздуха поднимались до $+1,1+7,5^{\circ} \mathrm{C}$, снег таял круглосуточно с интенсивностью от 1,5 до 61,5 мм/сутки. Дневное снеготаяние отмечалось 6 дней: с 9 по 12 марта, 19 и 24 марта, когда максимальная температура воздуха поднималась до $+1,7+7,2,+3,4$ и $+5,2{ }^{\circ} \mathrm{C}$ соответственно Процесс снеготаяния был достаточно интенсивным. Расчеты суточных величин снеготаяния и поверхностного стока показали, что снежный покров, эквивалентный накопленному за холодный период 2015-2016 гг. запасу воды 101,2 мм, на открытых площадках и газонах растаял полностью 3-4 апреля, а в лесопарках, на затененных площадках и газонах 13-14 апреля 2016 г. Весной 2016 г. суточные значения поверхностного стока варьировались в диапазоне 0,4-21,3 мм. На открытых площадках и газонах к 3-4 апреля суммарный поверхностный сток за счет атмосферных осадков увеличился до 102,3-123,7 мм. В лесопарках, на затененных площадках и газонах к 13-14 апреля вследствие влияния атмосферных осадков, испарения и фильтрации суммарный поверхностный сток находился в диапазоне 79,6-91,8 мм (табл. 2).

Весна 2017 г. не была такой дружной, и снеготаяние происходило иначе, чем весной 2016 г. В периоды потеплений при вторжениях теплых воздушных масс средние суточные температуры воздуха поднимались до $+0,3-+2,7{ }^{\circ} \mathrm{C}$. Вследствие чего в течение 9 суток с 4 по 7 марта, с 25 по 27 марта, 29 марта и 6 апреля 2017 г. снег таял круглосуточно с интенсивностью от 0,4 до 43,5 мм/сутки. Круглосуточное снеготаяние весной 2017 г. сменялось периодами похолодания (1-3, 8-24, 28 марта, с 30 марта по 5 апреля). Основной объем снега растаял днем. Дневное снеготаяние продолжалось 32 дня и происходило в два этапа - с 2 по 30 марта и с 3 по 5 апреля, когда максимальная температура воздуха поднималась до $+1,7$ $+7,2,+3,4$ и $+5,2^{\circ} \mathrm{C}$ соответственно. По проведенным расчетам снежный покров, эквивалентный накопленному за холодный период 2016-2017 гг. запасу воды 103,8 мм, полностью растаял на открытых газонах и площадках 7-8 апреля, в лесопарках и на затененных газонах и площадках - 14-15 апреля. В весенний сезон 2017 г. суточные значения поверхностного стока варьировались в диапазоне от -0,9 (снеготаяние меньше испарения) до 35,2 мм. На открытых площадках и газонах к 7-8 апреля суммарный поверхностный сток был равен 30,6-38,6 мм. В лесопарках, на затененных площадках и газонах к 14-15 апреля суммарный поверхностный сток варьировался от 63,7 до 98,9 мм (табл. 3).

Таблица 2. Снеготаяние, осадки, испарение, фильтрация и поверхностный сток (SM, Pr, E, I и SR, мм/сутки), суммарное снеготаяние и суммарный поверхностный сток ( $S S M$ и $\Sigma S R$, мм) в марте-апреле 2016 г.

Table 2. Snowmelt, precipitation, evaporation, infiltration and surface runoff (SM, Pr, E, I and SR, mm / day), total snowmelt and total surface runoff ( $\Sigma S M$ and $\Sigma S R, \mathrm{~mm}$ ) in March-April 2016

\begin{tabular}{|c|c|c|c|c|c|c|c|c|c|c|c|c|c|c|c|c|c|c|c|c|c|}
\hline Месяц/Month & \multicolumn{7}{|c|}{ Март/March } & \multicolumn{14}{|c|}{ Апрель/April } \\
\hline Даты/Dates & 25 & 26 & 27 & 28 & 29 & 30 & 31 & 1 & 2 & 3 & 4 & 5 & 6 & 7 & 8 & 9 & 10 & 11 & 12 & 13 & 14 \\
\hline $\begin{array}{l}\text { SM (лесопарк, зате- } \\
\text { ненные газоны и } \\
\text { площадки, a=1,4) } \\
\text { (forest park, shaded } \\
\text { lawns and sites, a=1,4) }\end{array}$ & 1,5 & 2,4 & 2,4 & 2,7 & 2,7 & 3,4 & 3,2 & 1,7 & 2,5 & 5,3 & 6,3 & 5,9 & 2,4 & 4,5 & 6,0 & 7,6 & 10,5 & 7,4 & 6,0 & 8,5 & 17,2 \\
\hline$\Sigma \mathrm{SM}$ & 1,5 & 3,9 & 6,3 & 9,0 & 11,6 & 15,0 & 18,2 & 19,9 & 22,4 & 27,7 & 34,0 & 39,9 & 42,3 & 46,8 & 52,8 & 60,3 & 70,8 & 78,3 & 84,3 & 92,8 & 110,0 \\
\hline $\begin{array}{l}\text { SM (открытые газоны } \\
\text { и площадки, a=5) } \\
\text { (open lawns and sites, } \\
\text { a=5) }\end{array}$ & 5,5 & 8,5 & 8,5 & 9,5 & 9,5 & 12,0 & 11,5 & 6,0 & 9,0 & 19,0 & 22,5 & 21,0 & 8,5 & 16,0 & 21,5 & 27,0 & 37,5 & 26,5 & 21,5 & 30,5 & 61,5 \\
\hline$\Sigma \mathrm{SM}$ & 5,5 & 14,0 & 22,5 & 32,0 & 41,5 & 53,5 & 65,0 & 71,0 & 80,0 & 99,0 & 121,5 & - & - & - & - & - & - & - & - & - & - \\
\hline $\operatorname{Pr}$ & - & 2,0 & 4,0 & 0,1 & 0,0 & - & - & 0,0 & 5,0 & 0,0 & - & 7,0 & 5,9 & 0,0 & - & - & 1,1 & 6,0 & 0,5 & - & - \\
\hline $\mathrm{E}$ & 1,1 & 0,4 & 0,4 & 0,4 & 0,9 & 1,2 & 1,2 & 0,9 & 0,5 & 0,9 & 1,2 & 0,4 & 0,4 & \begin{tabular}{|l|}
1,4 \\
\end{tabular} & 1,5 & 1,6 & 1,1 & 0,7 & 1,3 & - & - \\
\hline I & - & - & - & - & - & - & - & - & - & - & - & 2,5 & 2,5 & 2,5 & 2,5 & 2,5 & 2,5 & 2,5 & 5 & 5 & 5 \\
\hline $\begin{array}{l}\text { SR (лесопарк, зате- } \\
\text { ненные газоны и } \\
\text { площадки, a=1,4) } \\
\text { (forest park, shaded } \\
\text { lawns and sites, a=1,4) }\end{array}$ & 0,4 & 3,9 & 6,0 & 2,4 & 1,8 & 2,2 & 2,0 & 0,8 & 7,0 & 4,4 & 5,1 & 10,0 & 5,3 & 0,6 & 2,0 & 3,5 & 8,0 & 10,2 & 0,2 & 3,5 & 12,2 \\
\hline$\Sigma \mathrm{SR}$ & 0,4 & \begin{tabular}{|l|}
4,3 \\
\end{tabular} & 10,4 & 12,8 & 14,6 & 16,7 & 18,8 & 19,6 & 26,6 & 31,1 & 36,2 & 46,2 & 51,5 & 52,1 & 54,1 & 57,6 & 65,6 & 75,8 & 76,0 & 79,6 & 91,8 \\
\hline $\begin{array}{l}\text { SR (открытые газоны } \\
\text { и площадки, a=5) } \\
\text { (open lawns and } \\
\text { sites, a=5) }\end{array}$ & 4,4 & 10,1 & 12,1 & 9,2 & 8,6 & 10,8 & 10,3 & 5,1 & 13,5 & 18,1 & 21,3 & - & - & - & - & - & - & - & - & - & - \\
\hline$\Sigma \mathrm{SR}$ & 4,4 & 14,4 & 26,6 & 35,8 & 44,4 & 55,3 & 65,6 & 70,7 & 84,2 & 102,3 & 123,7 & - & - & - & - & - & - & - & - & - & - \\
\hline
\end{tabular}


Таблица 3. Снеготаяние, осадки, испарение, фильтраџия и поверхностный сток (SM, Pr, E, I и SR, мм/сутки), суммарное снеготаяние и суммарный поверхностный сток ( $\Sigma S M$ и $\Sigma S R$, мм) в марте-апреле 2017 г.

Table 3. Snowmelt, precipitation, evaporation, infiltration and surface runoff (SM, Pr, E, I and SR, mm / day), total snowmelt and total surface runoff ( $\Sigma$ SM and $\Sigma$ SR, mm) in March-April 2017

\begin{tabular}{|c|c|c|c|c|c|c|c|c|c|c|c|c|c|c|c|c|c|c|}
\hline Месяц/Month & \multicolumn{8}{|c|}{ Март/March } & \multicolumn{10}{|c|}{ Апрель/April } \\
\hline Даты/Dates & 4 & 5 & 6 & 7 & 25 & 26 & 27 & 29 & 6 & 7 & 8 & 9 & 10 & 11 & 12 & 13 & 14 & 15 \\
\hline $\begin{array}{l}\text { SM (лесопарк, затененные газоны и } \\
\text { площадки, } \mathrm{a}=1,4 \text { ) (forest park, shaded } \\
\text { lawns and sites, } a=1,4 \text { ) }\end{array}$ & 3,4 & 0,6 & 1,5 & 0,7 & 1,3 & 0,7 & 0,4 & 1,0 & 3,8 & 9,2 & 12,2 & 11,8 & 9,1 & 8,7 & 13,0 & 9,4 & 9,5 & 8,8 \\
\hline$\Sigma \mathrm{SM}$ & 3,4 & 4,0 & 5,5 & 6,2 & 7,5 & 8,2 & 8,6 & 9,6 & 13,4 & 22,6 & 34,8 & 46,6 & 55,7 & 64,4 & 77,4 & 86,8 & 96,3 & 105,1 \\
\hline $\begin{array}{l}\text { SM (открытые газоны и площадки, } \\
\text { a=5) (open lawns and sites, a = 5) }\end{array}$ & 12,0 & 2,0 & 5,5 & 2,5 & 4,5 & 2,5 & 1,5 & 3,5 & 13,5 & 33,0 & 43,5 & - & - & - & - & - & - & - \\
\hline$\Sigma \mathrm{SM}$ & 12,0 & 14,0 & 19,5 & 22,0 & 26,5 & 29,0 & 30,5 & 34,0 & 47,5 & 80,5 & 124,0 & - & - & - & - & - & - & - \\
\hline $\operatorname{Pr}$ & - & 0,0 & - & 0,0 & 0,0 & 1,0 & 0,0 & 0,3 & 0,0 & 0,0 & - & - & 0,0 & - & - & 0,0 & - & 5,1 \\
\hline $\mathrm{E}$ & 1,4 & 1,5 & 1,2 & 0,8 & 1,2 & 1,0 & 1,4 & 1,1 & 1,3 & 2,3 & 3,3 & 3,0 & 2,5 & 2,5 & 2,9 & 2,1 & 2,4 & 1,0 \\
\hline I & - & - & - & - & - & - & - & - & - & - & - & 2,5 & - & 2,5 & - & - & 2,5 & 2,5 \\
\hline $\begin{array}{l}\text { SR (лесопарк, затененные газоны и } \\
\text { площадки, } \mathrm{a}=1,4 \text { ) (forest park, shaded } \\
\text { lawns and sites, } \mathrm{a}=1,4 \text { ) }\end{array}$ & 2,0 & $-0,9$ & 0,3 & $-0,1$ & 0,1 & 0,7 & $-0,9$ & 0,2 & 2,5 & 2,0 & 3,9 & 6,3 & 1,6 & 3,7 & 5,1 & 2,3 & 2,1 & 7,9 \\
\hline$\Sigma$ SR & 2,0 & 1,1 & 1,4 & 1,3 & 1,4 & 2,1 & 1,2 & 1,4 & 3,8 & 5,7 & 9,6 & 15,9 & 17,5 & 21,2 & 26,2 & 28,5 & 30,6 & 38,6 \\
\hline $\begin{array}{l}\text { SR (открытые газоны и площадки, } a=5 \text { ) } \\
\text { (open lawns and sites, } a=5 \text { ) }\end{array}$ & 10,6 & 0,5 & 4,3 & 1,7 & 3,3 & 2,5 & 0,1 & 2,7 & 12,2 & 25,7 & 35,2 & - & - & - & - & - & - & - \\
\hline$\Sigma$ SR & 10,6 & 11,1 & 15,4 & 17,1 & 20,4 & 22,9 & 23,0 & 25,7 & 38,0 & 63,7 & 98,9 & - & - & - & - & - & - & - \\
\hline
\end{tabular}

Весной 2016 г. в лесопарках, на затененных газонах и площадках суммарный поверхностный сток за весь период снеготаяния составил 79,6-91,8 мм, на открытых газонах и площадках - 102,3-123,7 мм. В весенний сезон 2017 г. этот показатель был равен $30,6-38,6$ и 63,7-98,9 мм, что соответственно на $49-53,2$ и 24,8-38,6 мм меньше, чем весной 2016 г. К тому же поэтапно-прерывистый характер снеготаяния весной 2017 г. не способствовал формированию значительных суточных и суммарных объемов поверхностного стока и стока наносов.

В Екатеринбурге к концу зимы 2015-2016 гг. грунт без снежного покрова промерз на глубину 1,42 м (на 30 см меньше нормы, рассчитанной по [24], а к концу более суровой зимы 2016-2017 годов - на глубину 1,65 м (на 7 см меньше нормы), что на 17 см больше, чем в 2016 г. С учетом фактической высоты снежного покрова к концу зимы 2015-2016 гг. глубина промерзания составила $30 \mathrm{~cm}$, а концу зимы 2016-2017 гг. - 60 см, т. е. на 30 см больше, чем в марте 2016 г. (табл. 1).

Весной 2016 г. оттаивание грунта началось после схода снежного покрова, т. е. с 12 апреля. На 12 см грунт оттаял 15 апреля, а полностью - 17 мая. Весной 2017 г. оттаивание грунта началось раньше на 5 дней с 7 апреля. Вследствие похолодания и установления временного снежного покрова 9, 11, 16 и 17 апреля 2017 г. оттаивание грунта прекращалось. На 12 см грунт оттаял 12 апреля, на 28 см - 15 апреля, а полностью - 21 мая. С 18 мая, когда в обе весны временный снежный покров больше не устанавливался, разница оттаявшего грунта в 2017 и 2016 гг. составила 4 см. Всё это способствовало более интенсивной фильтрации талых вод в грунты в период после активного снеготаяния и вело к образованию меньшего количества грязевого осадка в апреле 2017 г., чем в апреле 2016 г.

\section{Заключение}

Проанализировано влияние метеорологических условий холодных периодов 2015-2016 и 2016-2017 гг. и весенних сезонов 2016 и 2017 гг. на формирование поверхностного стока в период весеннего снеготаяния в городе Екатеринбурге. При анализе учитывались термический режим приземной атмосферы, атмосферные осадки, характеристики снежного покрова, снеготаяния, промерзания и оттаивания грунтов. Показано, что следующие метеорологические параметры являлись определяющими при формировании поверхностного стока наносов и накопления грязевого осадка в период таяния снега:

- запас воды в снежном покрове к началу снеготаяния; - количество дней дневного снеготаяния;

- количество суток круглосуточного снеготаяния;

- сумма положительных температур за период снеготаяния;

- непрерывность или эпизодичность снеготаяния;

- возвраты холодов;

- атмосферные осадки в период снеготаяния.

Проведенный анализ показал, что сложившиеся метеорологические условия снеготаяния в рассматриваемые периоды могли привести к формированию различных суточных и суммарных объемов поверхностного стока талых вод и стока наносов. Несмотря на накопление примерно одинакового количества атмосферных осадков в снежном покрове за каждый из холодных периодов, специфика погодных условий весной 2016 г. была более благоприятной для формирования интенсивного поверхностного стока наносов, что соответствует качественным результатам наблюдения накопления грязевого осадка. Факторами, определившими образование больших суточных объемов поверхностного стока в весенний сезон 2016 г., явились: значительный запас воды, накопленный в снежном покрове за холодный период, дружная весна и интенсивное снеготаяние, не прерываемое похоло- 
даниями, дополнительные атмосферные осадки в период снеготаяния и медленное оттаивание грунта.

Таким образом, сравнение характеристик весеннего снеготаяния и наблюдение образования грязевого осадка в различные периоды показало, что наряду с накоплением твердого осадка существенную роль в

\section{СПИСОК ЛИТЕРАТУРЫ}

1. Taylor K. Urban environments. Environmental Sedimentology / Eds. Perry C., K. Taylor. - New Jersey: Wiley-Blackwell, 2007. - P. 190-222.

2. Taylor K.G., Owens P.N. Sediments in urban river basins: a review of sediment-contaminant dynamics in an environmental system conditioned by human activities // Journal of Soils and Sediments. - 2009. - V. 9 (4). - P. 281-303.

3. Challenges of the «Anthropocene»/ A. Chin, T. Beach, S. Luzzadder-Beach, W.D. Solecki // Anthropocene. - 2017. V. 20. - P. 1-3.

4. Russell K.L., Vietz G.J., Fletcher T.D. Global sediment yields from urban and urbanizing watersheds // Earth-Science Reviews. 2017. - V. 168. - P. 73-80.

5. Селезнев А.А. Тяжелые металлы в поверхностном грязевом осадке города Екатеринбурга // Известия Уральского государственного горного университета. - 2018. - № 1 (49). - С. 46-54.

6. Seleznev A.A., Yarmoshenko I.V., Sergeev A.P. Method for reconstructing the initial baseline relationship between potentially harmful element and conservative element concentrations in urban puddle sediment // Geoderma. - 2018. - V. 326. - P. 1-7.

7. US EPA 833-B-09-002. Developing your stormwater pollution prevention plan: a guide for industrial operators. - Washington, DC: United States Environmental Protection Agency, 2009. - 42 p.

8. An index to quantify street cleanliness: the case of Granada (Spain) $/$ A. Sevilla, M.L. Rodríguez, Á. García-Maraver, M. Zamorano // Waste Management. - 2013. - V. 33 (5). - P. 1037-1046.

9. Continental-scale pollution of estuaries with antibiotic resistance genes / Y.G. Zhu, Y. Zhao, B. Li, C.L. Huang, S.Y. Zhang, S. Yu, Y.S. Chen, T. Zhang, M.R. Gillings, J.Q. Su // Nat Microbiol. 2017. - V. 2:16270. - P. 1-7.

10. Tracing the sources of suspended sediment and particle-bound trace metal elements in an urban catchment coupling elemental and isotopic geochemistry, and fallout radionuclides / C. Froger, S. Ayrault, O. Evrard, G. Monvoisin, L. Bordier, I. Lefèvre, C. Quantin // Environmental Science and Pollution Research. 2018. - V. 25 (28). - P. 28667-28681.

11. Seleznev A., Rudakov M. Some geochemical characteristics of puddle sediments from cities located in various geological, geographic, climatic and industrial zones // Carpathian J of Earth and Env Sci. - 2019. - V. 14 (1). - P. 95-106.

12. Сает Ю.Е., Ревич Б.А., Янин Е.П. Геохимия окружающей среды. - М.: Недра, 1990. -335 с.

13. Оценка запасов современных пылегрязевых отложений на урбанизированной территории (на примере г. Екатеринбурга) / А.А. Селезнев, И.В. Ярмошенко, Г.П. Малиновский, Е.М. Баглаева // Биосферная совместимость: человек, регион, технологии. - 2018. - № 3 (23). - С. 74-85. формировании поверхностного стока наносов в современной урбанизированной среде играют метеорологические условия.

Исследование выполнено за счет гранта Российского научного фонда (проект № 18-77-10024).

14. Климат Свердловска / под ред. В.В. Морокова, Ц.А. Швер. Л.: Гидрометеоиздат, 1981. - 190 с.

15. Капустин В.Г., Корнев И.Н. География Свердловской области. - Екатеринбург: Изд-во «Сократ», 2006. - 400 с.

16. Алисов Б.П. Климат СССР. - М.: Изд-во МГУ, 1956. - 127 с.

17. Григорьев А.А., Будыко М.И. Классификация климатов СССР // Известия АН СССР. Сер. геогр. - 1959. - № 3. - С. 3-19.

18. Хромов С.П., Мамонтова Л.И. Метеорологический словарь. Л.: Гидрометеоиздат, 1974. -568 с.

19. Справочник по климату СССР. Вып. 9. История и физикогеографическое описание метеорологических станций и постов. - Свердловск: Фотоофсетная лаборатория Уральского УГМС, 1966. $-392 \mathrm{c}$

20. Российский гидрометеорологический энциклопедический словарь / под ред. А.И. Бедрицкого. Т. 1. - СПб.: Лет. сад, 2008. $-332 \mathrm{c}$

21. Швер Ц.А. Осадки на территории СССР. - Л.: Гидрометеоиздат, 1976. - 302 c.

22. Топ-50 городов по объему парка легковых автомобилей. URL: http://avtosreda.ru/news-common/Bolee55avtoparkaRossiiinomarki/ (дата обращения: 22.02.2019).

23. Архив погоды в Екатеринбурге. URL: http://rp5.ru/archive.php? wmo_id=28440 (даты обращения: 22.02.2019).

24. Научно-прикладной справочник по климату СССР. Серия 3. Ч. 1-6. Вып. 9. - Л.: Гидрометеоиздат, 1990. - 557 с.

25. Жустарёва Е.В., Фотиади А.А., Бочкарев В.И. Методические указания к практическим занятиям по дисциплине «Технологические процессы в строительстве». - М.: МАДИ, 2015. $48 \mathrm{c}$.

26. Михайлов В.Н., Добровольский А.Д. Общая гидрология. - Л.: Гидрометеоиздат, 1991. - $368 \mathrm{c}$

27. Жидиков А.П., Нечаева Н.С. Методические указания по разработке схем краткосрочных прогнозов расхода воды рек и протока воды в водохранилища в период половодья на основе моделей талого стока (на примере бассейна р. Волги) / под ред. к.т.н. В.А. Бельчикова. - Л.: Гидрометеоиздат, 1982. - 72 с.

28. Чеботарев А.И. Гидрологический словарь. - Л.: Гидрометеоиздат, 1978. $-308 \mathrm{c}$.

29. Грунтоведение / под ред. В.Т.Трофимова. 6-е изд. - М.: Изд-во МГУ, 2005. - $1024 \mathrm{c}$.

30. Общая гидрология (гидрология суши) / Б.Б. Богословский, А.А. Самохин, К.Е. Иванов, Д.П. Соколов. - Л.: Гидрометеоиздат, 1984. $-423 \mathrm{c}$.

31. Тетерин А.Ф. Изменения основных характеристик климата на Урале за период инструментальных наблюдений // Вестник Уральского отделения РАН. - 2013. - № 3 (45). - С. 44-55.

Поступила 19.11.2019 г.

\section{Информация об авторах}

Cелезнев $\boldsymbol{A}$.A., кандидат геолого-минералогических наук, старший научный сотрудник лаборатории урбанизированной среды Института промышленной экологии Уральского отделения РАН; доцент кафедры безопасности жезнедеятельности ФГАОУ ВО «УрФУ имени первого Президента России Б.Н. Ельцина».

Temepuн A.Ф., кандидат географических наук, старший научный сотрудник лаборатории урбанизированной среды Института промышленной экологии Уральского отделения РАН.

Ярмошенко И.В., кандидат физико-математических наук, заведующий лабораторией урбанизированной среды Института промышленной экологии Уральского отделения РАН. 
UDK 551.582:551.584:550.42:502.175

\title{
METEOROLOGICAL CONDITIONS OF SURFACE SEDIMENT RUNOFF FORMATION DURING SPRING SNOWMELT IN URBAN ENVIRONMENT
}

\author{
Andrian A. Seleznev1,2, \\ sandrian@rambler.ru \\ Alexander F. Teterin'1, \\ taf@ecko.uran.ru \\ Ilia V. Yarmoshenko', \\ ivy@ecko.uran.ru \\ 1 Institute of Industrial Ecology of Ural Branch of Russian Academy of Sciences, \\ 20, S. Kovalevskaya street, Yekaterinburg, 620219, Russia. \\ 2 Ural Federal University named after the first President of Russia B.N. Yeltsin, \\ 19, Mira street, Yekaterinburg, 620002, Russia.
}

\begin{abstract}
The relevance of the research is caused by the need to study sedimentation in urbanized area, which reduces the quality of urban environment and has negative effect on ecological situation.

The main aim of the research is to analyze the meteorological conditions of surface sediment runoff formation in a large city during the intense spring snowmelt.

Objects of the research is the urbanized area of the city of Yekaterinburg.

Methods: study of meteorological conditions for the cold periods of 2015-2016 and 2016-2017, as well as in the spring seasons of 2016 and 2017; assess the features and differences of meteorological parameters and processes that had a major impact on the sediment runoff in the spring of 2016 and 2017.

Results. The meteorological conditions of the cold periods 2015-2016 and 2016-2017 and the spring seasons 2016 and 2017 were reconstructed. Meteorological parameters and processes that had a significant impact on the sediment runoff in the urban area such as thermal regime of ground air, precipitation, snow cover, snowmelt, and freezing and thawing of soils were studied. The significant diference between meteorological conditions of the spring of 2016 and 2017 was found, that reflected in sedimentation and formation of more intense mud deposition in 2016. The following factors appear to be crucial for formation of surface sediment runoff in the urban environment in spring: water accumulated in the snow cover during the cold period of the year, characteristics of the thermal regime during snowmelt (duration, cold returns), precipitation and soil thawing intensity during the snowmelt. The results obtained can be used in planning the measures to improve the environmental situation in the urban areas.
\end{abstract}

\section{Key words:}

Urban environment, sedimentogenesis, meteorological conditions, snowmelt, surface runoff, mud sediment, Yekaterinburg.

The research was carried out on account of grant of Russian Scientific Foundation (project no. 18-77-10024).

\section{REFERENCES}

1. Taylor K. Urban environments. Environmental Sedimentology. Eds. C. Perry, K. Taylor. New Jersey, Wiley-Blackwell. 2007. pp. 190-222.

2. Taylor K.G., Owens P.N. Sediments in urban river basins: a review of sediment-contaminant dynamics in an environmental system conditioned by human activities. Journal of Soils and Sediments, 2009, vol. 9 (4), pp. 281-303.

3. Chin A. Urban transformation of river landscapes in a global context. Geomorphology, 2006, vol. 79 (3-4), pp. 460-487.

4. Russell K.L., Vietz G.J., Fletcher T.D. Global sediment yields from urban and urbanizing watersheds. Earth-Science Reviews, 2017, vol. 168, pp. 73-80.

5. Seleznev A.A. Heavy metals in surface mud sediment in Ekaterinburg (Russia). News of the Ural State Mining University, 2018, no. 1 (49), pp. 46-54. In Russ.

6. Seleznev A.A., Yarmoshenko I.V., Sergeev A.P. Method for reconstructing the initial baseline relationship between potentially harmful element and conservative element concentrations in urban puddle sediment. Geoderma, 2018, vol. 326, pp. 1-7.

7. US EPA 833-B-09-002. Developing your stormwater pollution prevention plan: a guide for industrial operators. Washington, DC, United States Environmental Protection Agency, 2009. 42 p.

8. Sevilla A., Rodríguez M.L., García-Maraver Á., Zamorano M. An index to quantify street cleanliness: The case of Granada (Spain). Waste Management, 2013, vol. 33 (5), pp. 1037-1046.
9. Zhu Y.G., Zhao Y., Li B., Huang C.L., Zhang S.Y., Yu S., Chen Y.S., Zhang T., Gillings M.R., Su J.Q. Continental-scale pollution of estuaries with antibiotic resistance genes. Nat Microbiol, 2017, vol. 2:16270, pp. 1-7.

10. Froger C., Ayrault S., Evrard O., Monvoisin G., Bordier L., Lefèvre I., Quantin C. Tracing the sources of suspended sediment and particle-bound trace metal elements in an urban catchment coupling elemental and isotopic geochemistry, and fallout radionuclides. Environmental Science and Pollution Research, 2018, vol. 25 (28), pp. 28667-28681.

11. Seleznev A., Rudakov M. Some geochemical characteristics of puddle sediments from cities located in various geological, geographic, climatic and industrial zones. Carpathian J of Earth and Env. Sci., 2019, vol. 14 (1), pp. 95-106.

12. Saet Yu.E. Geokhimiya okruzhayushchey sredy [Environmental geochemistry]. Moscow, Nedra Publ., 1990. 335 p.

13. Seleznev A.A., Yarmoshenko I.V., Malinovsky G.P., Baglaeva E.M. Total amount of contemporary dirt and dust sediments in an urban environment (on the example of Ekaterinburg, Russia). Biosphere compatibility: human, region, technologies, 2018, no. 3 (23), pp. 74-85.

14. Klimat Sverdlovska [Climate of Sverdlovsk]. Eds. V.V. Morokov, C.A. Shver. Leningrad, Gidrometeoizdat Publ., 1981. 190 p.

15. Kapustin V.G., Kornev I.N. Geografiya Sverdlovskoy oblasti [Geography of Sverdlovsk oblast]. Ekaterinburg, Sokrat Publ., 2006. $400 \mathrm{p}$. 
16. Alisov B.P. Klimat SSSR [Climate of the USSR]. Moscow, MGU Publ., 1956. $127 \mathrm{p}$.

17. Grigorev A.A., Budyko M.I. Klassifikatsiya klimatov SSSR [Classification of climates in the USSR]. Izvestiya AN SSSR. Ser. geogr., 1959, no. 3, pp. 3-19.

18. Khromov S.P., Mamontova L.I. Meteorologicheskiy slovar [Meteorological dictionary]. Leningrad, Gidrometeoizdat Publ., 1974. $568 \mathrm{p}$.

19. Spravochnik po klimatu SSSR. Vypusk 9. Istoriya i fizikogeograficheskoe opisanie meteorologicheskikh stantsiy i postov [Guide to the climate of the USSR. Iss. 9. History and physiographic description of meteorological stations and posts]. Sverdlovsk, Fotoofsetnaya laboratoriya Uralskogo UGMS Publ., 1966. $392 \mathrm{p}$.

20. Rossiyskiy gidrometeorologicheskiy entsiklopedicheskiy slovar [Russian hydrometeorological encyclopedic dictionary]. Ed. by A.I. Bedritsky. St-Petersburg, Let. Sad Publ., 2008. Vol. 1, 332 p.

21. Shver C.A. Osadki na territorii SSSR [Precipitation in the USSR] Leningrad, Gidrometeoizdat Publ., 1976. 302 p.

22. Top-50 gorodov po obemu parka legkovykh avtomobiley [Top 50 cities by car park]. Available at: http://avtosreda.ru/newscommon/Bolee55avtoparkaRossiiinomarki/ (accessed 22 February 2019).

23. Arkhiv pogody $v$ Ekaterinburge [Ekaterinburg weather archive]. Available at: http://rp5.ru/archive.php?wmo_id=28440 (accessed 22 February 2019).

24. Nauchno-prikladnoy spravochnik po klimatu SSSR [Applied handbook on the USSR climate]. Leningrad, Gidrometeoizdat Publ., 1990. Ser. 3, P. 1-6, Iss. 9, 557 p.

25. Zhustaryova E.V., Fotiadi A.A., Bochkarev V.I. Metodicheskie ukazaniya $k$ prakticheskim zanyatiyam po distsipline
«Tekhnologicheskie protsessy v stroitelstve» [Guidelines for practical classes on the discipline «Technological processes in construction»]. Moscow, MADI Publ., 2015. 48 p.

26. Mikhaylov V.N., Dobrovolskiy A.D. Obshchaya gidrologiya [General hydrology]. Leningrad, Gidrometeoizdat Publ., 1991. $368 \mathrm{p}$.

27. Zhidikov A.P., Nechaeva N.S. Metodicheskie ukazaniya po razrabotke skhem kratkosrochnykh prognozov raskhoda vody rek $i$ protoka vody $v$ vodokhranilishcha $v$ period polovodya na osnove modeley talogo stoka (na primere basseyna $r$. Volgi) [Guidelines for development of schemes for short-term forecasts of river flow and water flow in reservoirs during the flood period based on models of thawed snow (using the Volga river basin as an example)]. Ed. by V.A. Belchikov. Leningrad, Gidrometeoizdat Publ., 1982. $72 \mathrm{p}$.

28. Chebotarev A.I. Gidrologicheskiy slovar [Hydrological dictionary]. Leningrad, Gidrometeoizdat Publ., 1978. 308 p.

29. Gruntovedenie [Soil science]. Ed. by V.T. Trofimov. Moscow, MGU Publ., 2005. 1024 p.

30. Bogoslovskiy B.B., Samokhin A.A., Ivanov K.E., Sokolov D.P. Obshchaya gidrologiya (gidrologiya sushi) [General hydrology (land hydrology)]. Leningrad, Gidrometeoizdat Publ., 1984. 423 p.

31. Teterin A.F. Izmeneniya osnovnykh kharakteristik klimata na Urale za period instrumentalnykh nablyudeniy [Changes in the main characteristics of the climate in the Urals over the period of instrumental observations]. Vestnik Uralskogo otdeleniya RAN, 2013, no. 3 (45), pp. 44-55.

Received: 19 November 2019

\section{Information about the authors}

Andrian A. Seleznev, Cand. Sc., senior researcher, Institute of Industrial Ecology of Ural Branch of Russian Academy of Sciences; associate professor, Ural Federal University named after the first President of Russia B.N. Yeltsin.

Alexander F. Teterin, Cand. Sc., senior researcher, Institute of Industrial Ecology of Ural Branch of Russian Academy of Sciences.

Ilia V. Yarmoshenko, Cand. Sc., head of laboratory, Institute of Industrial Ecology of Ural Branch of Russian Academy of Sciences. 